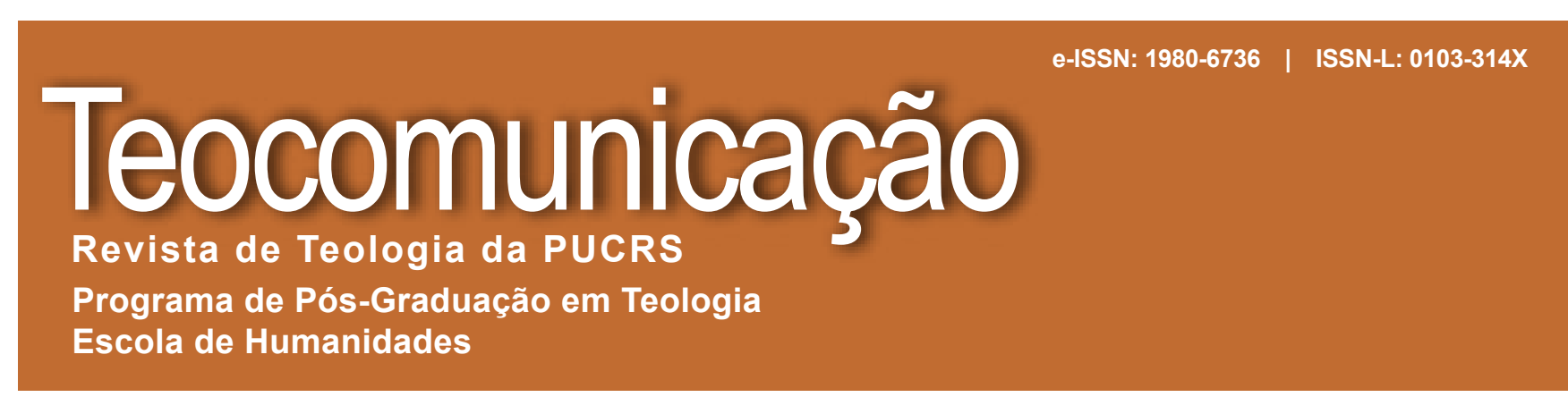

\title{
Participar da Santidade de Deus
}

\section{To participate in God's Holiness}

\section{Maria Clara Lucchetti Bingemer ${ }^{1}$}

\section{RESUMO:}

$\mathrm{O}$ artigo focaliza o chamado à santidade segundo o Cristianismo seguindo a exortação de Francisco, chamado dirigido a toda a Igreja. Examina como a história das ideias, a filosofia e a teologia utilizam o conceito de santo e santidade, detendo-se especialmente na figura do santo como testemunha. Em seguida lança o olhar sobre a realidade da América Latina, examinando como algumas teologias contextuais perceberam aí a presença de uma santidade primordial, anterior a toda definição e a toda apropriação mesmo por parte da Igreja. Mais adiante reflete como a santidade tem uma configuração crística, que procura alcançar a proximidade e a semelhança com Jesus Cristo. Nesse sentido examina as opções que o Papa Francisco recomenda como caminho para aceder a essa identificação com o Senhor. Finalmente focaliza a categoria que o Papa privilegia como caminho para responder ao chamado à santidade: o discernimento.

Palavras-chave: Santidade. Testemunha. Discernimento.

\section{ABSTRACT:}

The article focuses on the call to holiness according to Christianity following the exhortation of Francis, a call addressed to the whole Church. It examines how the history of ideas, philosophy, and theology use the concept of saint and holiness, focusing especially on the saint's figure as a witness. It then looks at the reality of Latin America, examining how some contextual theologies perceive the presence of primordial holiness, prior to all definition and appropriation even by the Church. It further reflects how holiness has a Christ configuration that seeks to achieve closeness and resemblance to Jesus Christ. In this sense, it examines the options that Pope Francis recommends as a way to access this identification with the Lord. Finally, it focuses on the category the Pope favors as a way to respond to the call to holiness: discernment.

Keywords: Holiness. Witness. Discernment. 


\section{INTRODUÇÃO}

cegundo a Bíblia judaica, só Deus é santo e a Ele não se pode ver sem morrer. No Novo $\checkmark$ Testamento, Jesus Cristo é proclamado o Santo de Deus, ou seja, Aquele sobre quem repousa a santidade divina. Com sua morte e ressurreição, é derramado sobre toda carne esse Espírito de Santidade. E os seguidores de Jesus são chamados a dar diante do mundo o testemunho dessa santidade que é divina e ao mesmo tempo dada ao ser humano como dom. Pela inhabitação do Espírito Santo, a santidade passa a habitar o ser humano e assim se encontra acessível a todos e todas que seguem a Jesus e vivem como ele e em comunhão com ele e seu Pai.

A santidade, portanto, é o destino e a meta da vida de todo cristão. Baseado nesta convicção, o Papa Francisco escreve sua exortação apostólica Gaudete et Exsultate "Alegraivos e exultai". Deseja ele que vivamos plenamente aquilo que o Senhor nos propõe: uma vida que não se contente com a banalidade, a mediocridade ou a indecisão ( $G E$ 1). Uma vida plena, ali onde estamos, no tempo e espaço que ocupamos. É ali que somos chamados a fazer nossas escolhas, respondendo aos desafios que nos são feitos. E ouvindo e respondendo aos chamados de Deus que nos chegam no momento da história que nos toca viver.

Longe de escrever um tratado sobre a santidade, o que pretende o Papa é apenas uma coisa: que o chamado à santidade ressoe uma e outra vez no mundo de hoje, fazendo entender que ser santo é na verdade ser profunda e radicalmente humano: criado, redimido e santificado por Deus em seu amor infinito (GE 2). É, em suma, participar da santidade divina.

Neste texto procuraremos refletir sobre o chamado à santidade segundo o Cristianismo seguindo a exortação de Francisco dirigida a toda a Igreja. Primeiro procuraremos ver como a história das ideias, a filosofia e a teologia utilizam o conceito de santo e santidade. Vamos deter-nos especialmente sobre a figura do santo como testemunha. Em seguida lançaremos o olhar sobre a realidade da América Latina, vendo como algumas teologias contextuais perceberam aí a presença de uma santidade primordial, anterior a toda definição e a toda apropriação mesmo por parte da Igreja. Mais adiante, refletiremos como a santidade tem uma configuração crística, já que o santo na verdade deseja ser e procura alcançar a proximidade e maior semelhança com Jesus Cristo. Nesse sentido examinaremos as preferencias e opções que o Papa Francisco recomenda como caminho para aceder a essa identificação com o Senhor. Finalmente concluiremos refletindo sobre a categoria que o Papa privilegia como caminho para responder ao chamado à santidade: o discernimento ${ }^{3}$.

\section{SANTIDADE: ETIMOLOGIA, DEFINIÇÃO, CONCEITO}

Etimologicamente a raiz da palavra santo ou santidade é complexa. Em latim clássico, sanctus (santo) se refere a sanctio, sancire (sanção, sancionar) e se aproxima de sacer, sacrare (sagrado, consagrado). Santo é, portanto, aquele que não "pertence" à realidade onde está situado e sim a Outro a Quem obedece. É alguém "sancionado"4 separado do profano, reservado pelos deuses. Remete àquilo que é inviolável e que não faz número com as outras coisas, e que por isso situa-se em uma esfera que o faz não poder ser tratado com mera familiaridade 5 .

A exortação apostólica Gaudete et Exsultate (GE) foi promulgada em 19 de março de 2018.

Seguiremos de perto neste artigo o livro no qual desenvolvemos mais amplamente a reflexão teológica sobre a GE: Santidade. Chamado à humanidade. Reflexões sobre a Exortação Apostólica Gaudete et Exsultate. São Paulo: Paulinas, 2019.

4 A etimologia de sanção é: lat. sanctio,ónis 'ação de sancionar, sanção', do rad. de sanctum supn. de sancio,is,sanxi ou sancívi,sanctum ou sancítum, sancíre 'tornar sagrado ou inviolável; estabelecer solenemente por meio de uma lei; ratificar'. E santo tem a etimologia apontada como: lat. sanctus, a,um 'que tem caráter sagrado, augusto, venerando, inviolável, respeitável'; no lat.ecl. s.m. 'bem-aventurado', do part. de sancio,is,xi,ctum,cire 'dar, pôr, estabelecer; nomear, criar; ordenar, prescrever, mandar; marcar, designar, consagrar, dedicar, livrar, purificar'; ver sant-; f.hist. sXIII santo, sXIII sanctos, 1391 sante, sXIV sãcto, sXIV ssãtas; cf. HOUAISS, Antônio; VILLAR, Mauro de Salles. Sanção. Santo. In: Dicionário Houaiss.

Cf. a clássica reflexão de Rudolf Otto sobre o numinoso, "tremendum et fascinans” no livro: O Sagrado. 
Assim, quando uma realidade, uma pessoa humana, um deus são declarados santos, é mais uma questão de diferença absoluta, de não equiparação às outras coisas, de interdito ritual, do que de uma bondade intrínseca, que provoca veneração ou louvor. A Bíblia judaica e também a cristã adotam este conceito de santidade, sinônimo de alteridade e diferença, feito de pureza, justiça, perfeição - que seduz ao mesmo tempo em que surpreende. Na visão bíblica, a santidade está diretamente ligada à revelação de Deus, o Santo, na história, embora conservando toda a Sua Transcendência. No Cristianismo, afirma-se que o Deus Santo se fez carne e que existem seres humanos que podem aproximar-se de maneira muito intensa de Deus, seu ser e sua ação participando de sua santidade ${ }^{6}$. Com a morte e ressurreição de Jesus - Verbo Encarnado - é derramado sobre seus seguidores o Espírito Santo e a santidade então se encontra acessível a todos e todas que vivem como Jesus.

Pessoas declaradas santas, canonizadas ou não, propõem um ideal de ser humano composto ao mesmo tempo por uma profunda vida interior, uma liberdade a toda prova e uma preocupação de agir "em favor dos outros", tornando assim visível o fruto das obras de Deus através de suas pessoas. Sua liberdade independe de condições econômicas e sociais. E é libertadora não apenas no plano espiritual, mas também no social, seja pelas obras e as opções assumidas, ou seja, eventualmente, pelas rupturas que a elas se seguem ou que a elas se antecipam ${ }^{7}$.

Santidade é vocação e destino pessoal. Resulta menos da execução de um programa ascético-moral do que de uma resposta absoluta e amorosa ao chamado e à vontade de Deus. Eis porque é bastante independente de projeção social ou psiquismo "saudável": não está fechada ou fora do alcance de sujeitos que padeçam de alguma desgraça ou patologia natural ${ }^{8}$. O desejo e o esforço para responder a Deus engaja o ser humano na busca de uma radicalidade espiritual e moral. E o chamado de Deus é imprevisível, irredutível às condições globais de vida, tal como os exemplos concretos de santos testemunham ${ }^{9}$. Eis porque as fronteiras entre santidade e loucura são às vezes não tão visíveis e perceptíveis ${ }^{10}$.

Este chamado ressoa diferentemente segundo o contexto histórico, social e cultural no qual acontece. A resposta da santidade está na maioria das vezes em harmonia com as exigências dos tempos e espaços em que vivem os santos.

O santo é uma pessoa "ex-cêntrica", uma vez que é sempre Outro quem o guia. Ao mesmo tempo, trata-se de pessoa bem consciente da própria fragilidade. Seu heroísmo consiste em consentir em ser conduzido por esse Outro, de forma que o poder divino se manifeste sobretudo ali onde a humanidade é com maior evidência mais fraca e impotente ${ }^{11}$. Já o afirma o mesmo Paulo de Tarso, ao dizer com inexplicável gozo em meio a tormentos e tribulações: "Por isso sinto prazer nas fraquezas, nas injúrias, nas necessidades, nas perseguições, nas angústias por amor de Cristo. Porque quando estou fraco então sou forte" (2 Cor 12,10).

Se se define cada ato humano como livre e responsável e o ser humano é concebido na modernidade que moldou o pensamento ocidental mais recentemente como alguém que existe porque pensa e se concebe em termos de conhecimento e consciência ${ }^{12}$, o santo parece explodir em pedaços a matriz conceitual desta definição. Seu conhecimento é revertido pela entrega amorosa ao Outro que o conhece e o ama. Experimentando-se

Cf. ENCYCLOPAEDIA UNIVERSALIS. Sainteté.

Queremos dizer aqui que alguém pode levar uma vida e adotar uma prática que pode ser qualificada de santa, devido às opções que ele ou ela assumem no meio social em que vivem e partindo de suas escolhas cotidianas sociais e políticas.

A psicologia tem sido pródiga em apontar patologias na vida e no comportamento de muitos santos e místicos. Cf. CLÉMENT, C.; KHAKAR, S. A louca e o santo. Assim também BYNUM, Carolyn Walker. Holy Feast and Holy Fast; ou VASSE, Denis. L'autre du désir ou le Dieu de la foi.

9 Poderíamos citar aqui Charles de Foucauld que era um nobre militar e acabou sua vida como um solitário ermitão no deserto africano. Ou Benoit Labre que optou por levar uma vida de mendigo a fim de testemunhar a Jesus e pregar o Evangelho. Entre muitos outros

10 Ver por exemplo alguns dos personagens de Fiódor Dostoievsky, como o Príncipe Pouchkine, de "O Idiota" ou mesmo as palavras de São Paulo sobre a loucura da Cruz (cf. 1 Cor $1,18 \mathrm{ss}$ )

${ }_{11}$ Ver sobre isto: MATHON, G. Sainteté, in Catholicisme hier, aujourd'hui et demain, p. 704.

12 Cf. o célebre "cogito" cartesiano: "Penso logo existo". 
conhecido e amado, entrega-se inteiramente a este Outro por cujas mãos se deixa levar. E é então que começa a acontecer uma nova forma de conhecimento, de ciência. O santo conhece "ignorantemente", "amorosamente". Na verdade, "aprende" cada passo a ser dado na medida em que se aprofunda na aventura do amor que lhe "ensina" 13 . Os frutos de sua ação então nascem em misteriosa imprevisibilidade. E são configurados como certeza de não saber, de não possuir nenhum poder sobre sua própria prática e comportamento. A única coisa que "sabe" é que não é possível não ser o que é e não fazer o que faz, porque essa é a vontade de Deus. Veja-se sobre isso entre outros o apaixonado Paulo de Tarso que clamava cheio de desejo e consolação: "Ai de mim se eu não evangelizar" (1 Cor 9,16).

A despeito do fato de que as hagiografias tradicionais enfatizem a ascese implacável, as terríveis penitencias e o exercício das virtudes morais em nível heroico nas vidas dos santos, é importante não perder de vista duas coisas: a primeira é que a santidade não é uma performance ou um campeonato pela qual se espera ganhar um prêmio ou uma medalha. Ao contrário, ela se verifica na capacidade de humilde e fielmente realizar as pequenas exigências do cotidiano com amor e paciência; a segunda é o fato de que a grandeza e a autenticidade do santo não dependem tanto de reconhecimento social ou mesmo eclesiástico. Está situada em um horizonte maior: o Mistério do ser divino, experimentado sempre em uma maneira original e nova, que é como um fogo que a tudo consome. Nesse sentido há muitos santos não canonizados pela Igreja, sem coroa nem capela, mas que viveram radicalmente a entrega a Deus e à missão a eles e elas confiada por Deus fora dos limites institucionais da Igreja.

Amigo de Deus e amigo da vida, o santo mostra a possibilidade de viver a "intimidade com Deus" voltado em amorosa misericórdia para o mundo e a humanidade ${ }^{14}$. O Papa Francisco, em sua Exortação, seguirá esta linha que conecta o santo não só vertical e interiormente com Deus e Seu Espírito, mas horizontalmente (com os irmãos) aos quais é levado a amar e servir impulsionado pelo mesmo Espírito do mesmo Deus.

\section{O SANTO: UMA TESTEMUNHA}

No Capítulo I da Exortação, o Papa já inicia sua reflexão com uma categoria profunda e rica de significado: o testemunho. Citando a Carta aos Hebreus, menciona a "nuvem de testemunhas" que acompanham os cristãos e os estimulam a não se deter no caminho, mas a correr para a meta (Heb 12,1). Porém, para que não pensemos que essas testemunhas se situam em um tempo e espaço longínquos, demasiado elevadas para que as alcancemos, menciona que elas podem estar muito próximas de nós: "nossa própria mãe, uma avó..." citando 2 Tim 1,5.

A fé cristã foi desde seus começos uma fé no testemunho de outros. Os discípulos acreditaram em Jesus, no qual reconheceram e ao qual proclamaram Testemunha Fiel. As mulheres acreditaram que o túmulo não era o lugar daquele que estava vivo. Os apóstolos - depois de certa relutância - acreditaram nas mulheres. E assim começou o caminho dessa proposta de vida que foi conquistando o mundo conhecido de então, forte apenas da palavra de alguns frágeis seres humanos que diziam: "Isso é verdade porque eu vi, eu experimentei. Dou testemunho e sou capaz de morrer por isso".

A fé cristã desde seus inícios é, portanto, uma fé de testemunhas e não tanto de textos. Cada vez se torna mais verdadeira e verificável a afirmação de que há que fazer uma teologia não de textos, mas de testemunhas. O Papa chama a atenção para o fato de que

Cf. o adulto militar e nobre Inácio de Loyola, que constata que Deus o conduz "como um mestre-escola a um menino". Autobiografia, n. 27. Citamos aqui Simone Weil em Attente de Dieu, p 62: "Hoje não é ainda nada ser um santo, é necessária a santidade que o momento presente exige, uma santidade nova, ela também sem precedente". 
essas testemunhas nos ajudam não apenas dando-nos seu testemunho inspirador para nossa caminhada aqui. Mas, tendo já chegado à presença de Deus, mantêm conosco laços de amor e comunhão ( $G E 4)$. E podem ser por nós invocados, admirados e seguidos.

Heróis da fé e da caridade - Alguns são verdadeiros heróis da fé, da esperança e da caridade. Homens e mulheres que viveram e vivem despojados de todo conforto, de toda segurança. Pessoas que foram capazes de sacrificar a própria vida no martírio cruento e radical, - como por exemplo Monsenhor Oscar Romero - ou no oferecimento generoso da vida gota a gota até o último suspiro no serviço aos últimos como Madre Teresa de Calcutá.

Mostraram-se capazes de uma entrega e uma doação que nos impressiona e nos faz estremecer. Olhando-os, vemos com mais clareza nossa mediocridade e covardia em responder aos apelos de Deus, mas também percebemos com esperança que são pessoas como nós, humanas como nós somos. E que, se puderam em suas vidas limitadas e finitas chegar a esse grau de heroísmo, dignificam o gênero humano ao qual eles e nós pertencemos.

No entanto, para que não pensemos que santidade é sinônimo de heroísmo e morte violenta, o Papa Francisco fala, na segunda seção deste capítulo I, dos "santos ao pé da porta”. E parte de um princípio pneumatológico. Podemos ser santos porque Deus é santo e, além de enviar Seu Filho, derrama seu Espírito que atua em nós e nos faz santos. "O Espírito Santo derrama a santidade por toda parte, no santo povo fiel de Deus" (GE 6).

Sublinha ainda o Papa que a santidade não é aventura individual, mas sim empresa comunitária e coletiva. A pertença a um povo é constitutiva de sua identidade. Na história da salvação, o interlocutor de Deus é o povo e não um indivíduo. Por isso ninguém se salva sozinho, senão que "Deus atrai-nos tendo em conta a complexa rede de relações interpessoais que se estabelecem na comunidade humana: Deus quis entrar em uma dinâmica popular, na dinâmica de um povo" ( $G E$ 6).

Testemunhas simples do cotidiano - Onde podemos encontrar, então, esses santos que estão a nosso lado, ao pé da nossa porta? Segundo Francisco, no povo paciente de Deus: na família, nos pais que criam os filhos com amor apesar das dificuldades; na gente que trabalha incansavelmente por anos para trazer o pão para casa; nos doentes e idosos que continuam a sorrir. Poderíamos acrescentar inúmeros exemplos àqueles mencionados pelo pontífice. Mulheres que criam os filhos sozinhas após serem abandonadas pelos companheiros; trabalhadores e trabalhadoras que permanecem por toda a sua vida em um trabalho honesto e mal remunerado e ainda encontram tempo e entusiasmo para animar as comunidades, trabalhar na pastoral e organizar lindas liturgias para que o povo reze e encontre a Deus.

A esses o Papa chama de "a classe média da santidade"15. Sua resposta ao chamado de Deus é feita de constância, persistência, fidelidade a um caminho que se faz no dia a dia. Aí vê Francisco a santidade da Igreja militante, constante e cotidiana, que pode estar perto de nós refletindo a presença de Deus.

Nesses se constrói a verdadeira história da salvação, ainda que permaneçam anônimos e ocultos, não revelados pela história oficial. Só Deus detém o segredo da fecundidade que têm suas vidas e da força santificadora de seu testemunho humilde e abnegado. Francisco cita para apoiar sua afirmação uma santa do século XX, Edith Stein, Santa Teresa Benedita da Cruz. Ela afirma ser através de muitos desses santos anônimos e pouco "importantes" aos olhos do mundo e da própria Igreja que se constrói a verdadeira história. Escrevendo a partir dos abismos escuros e tenebrosos do Holocausto e da perseguição ao seu próprio povo judeu, Edith/Teresa diz que

MALEGUE, Joseph. Pierres noires, citado em: GE 7, nota a. 
a corrente vivificante da vida mística permanece invisível. Certamente, os eventos decisivos da história do mundo foram essencialmente influenciados por almas sobre as quais nada se diz nos livros de história. E saber quais sejam as almas a quem devemos agradecer os acontecimentos decisivos da nossa vida pessoal, é algo que só conheceremos no dia em que tudo o que está oculto for revelado ${ }^{16}$.

\section{A SANTIDADE PRIMORDIAL}

A teologia latino-americana tem refletido sobre o fato teologal das pessoas que vivem uma santidade - ou seja uma total intimidade com Deus e uma total doação aos outros - em meio a situações onde isso seria humanamente impossível. A esse fenômeno, o teólogo Jon Sobrino tem chamado de santidade primordial. Em meio a uma pobreza extrema ou a catástrofes que lhes subtraíram violentamente todo o pouco que lhes restava para viver, mulheres salvaram o que puderam salvar e continuaram a dedicar-se ao cuidado da vida, cozinhando, partilhando, cuidando dos filhos seus e dos outros. Homens com algum vigor físico moviam montanhas de terra derrubadas por um terremoto e faziam o possível e o impossível para resgatar cadáveres e pessoas soterradas. Aí aparece ao mesmo tempo a tragédia e o encanto da humanidade e do humano: o sofrimento terrível que revela a santidade primordial ${ }^{17}$.

Quando a condição humana tem tudo para se animalizar e perder a dignidade, muitas vezes, em lugar disso, eleva-se com uma dignidade e uma altura espantosas. E isso pode se dar com conotações de heroísmo como já foi dito acima, mas pode dar-se igualmente em termos de um suportar o cotidiano extremamente difícil, injusto e violento não perdendo por isso a alegria, a solidariedade e a capacidade de amar.

Assim, essa "santidade primordial", como diz Jon Sobrino e que se aproxima bastante do que o Papa Francisco em sua exortação chama de "santidade ao pé da porta", se dá na vida de cada dia das pessoas pobres, simples e humildes. Diz o teólogo basco-salvadorenho que "para muitos seres humanos é seu modo habitual de vida. E ocorre em diversos graus dentro de uma gama muito ampla"18.

No mundo de hoje muitos milhões de pessoas passam fome diariamente. Nos países mais pobres, do antigamente chamado Terceiro Mundo, alguns morrem ao nascer ou pouco depois de nascer, sucumbindo a uma mortalidade que é fruto da falta de elementares cuidados. Assim o comprovou no Brasil a Pastoral do menor, que apenas assistindo às mulheres durante a gravidez e provendo às bebês coisas tão simples como o soro caseiro conseguiram baixar a mortalidade infantil de maneira notável ${ }^{19}$.

Existem nações inteiras que foram riscadas do mapa das grandes potências, como boa parte dos países da África e, mais perto de nós, o Haiti. Ali a fome, as epidemias, a injustiça gritante vai ceifando vidas em ritmo acelerado e constante. Além da injustiça, existe outro inimigo da vida que tem um enorme potencial predatório: a violência. Em muitos países da América Latina, com destaque para o Brasil, assim como outros países da América Central: El Salvador, Nicarágua, Honduras e também o México há ondas devastadoras de homicídios que é como uma epidemia que deixa um rastro de morte e horror.

STEIN, Edith. Vida escondida e epifania, p 637, citado em: $G E$ 8, nota 6.

SOBRINO, Jon. La santidad primordial, p. 365-377. O autor cita aqui Terremoto, terrorismo, barbarie y utopía. El Salvador, Nueva York, Afganistán, San Salvador.

18 SOBRINO, Jon. La santidad primordial.

19 Fundada pela Dra. Zilda Arns, que se encontra atualmente em processo de canonização, a pastoral do menor se estende hoje além do Brasil em vários países, diminuindo a mortalidade infantil. https://www.pastoraldomenor.com.br/ acessado em 23 de março de 2019. 
As vítimas em geral são jovens, pobres e afrodescendentes. E as famílias sofrem o impacto que sua morte acarreta. As mães desses jovens assassinados são as únicas que jamais desistem de reclamar seus corpos para enterrá-los. Muitas vezes organizam campanhas para pedir paz e evitar que outros passem pelo mesmo destino que seus filhos. E continuam vivendo e participando da comunidade, dando um extraordinário testemunho de resiliência e de esperança ali onde só o desespero parece reinar.

Essas imensas maiorias atingidas em cheio em suas vidas pela sombra da morte, seja através da injustiça como da violência são comparáveis aos "anawim" da Bíblia, os pobres de $\mathrm{Javé}^{20}$. Vivem abrumados sob um peso intolerável e a cada dia têm que lutar contra a ameaça a suas vidas. Devem "buscar a vida" pelo trabalho cansativo ao extremo, pelo viver em circunstancias sempre perigosas, pelo esforço de levantar a cabeça em meio a um sistema que não cessa de empurrá-los para as margens da sociedade. São os oprimidos, marginalizados, desprezados de todas as categorias. A Bíblia Hebraica e Cristã nomeou-os pluralmente: o pobre, o órfão, a viúva, o estrangeiro, os publicanos, as prostitutas, os leprosos, etc.

Muitos desses vivem vidas obscuras, escondidas, esmagadas. E mesmo assim encontram força não só para seguir adiante como até mesmo para ajudar os que lhes estão próximos. Assim, são vidas em si luminosas, mas que na maioria das vezes não são percebidas como tais por quase ninguém, inclusive pela própria Igreja ${ }^{21}$.

Alguns teólogos latino-americanos perceberam e refletiram sobre a santidade primordial dessas pessoas que não teriam nenhuma razão para esperar e, no entanto, esperam; não teriam nenhuma razão para amar e, no entanto, amam. São plenamente humanas porque cultivam o mínimo do humano, ou mais ainda, escolhem o que é humano e humanizador diante de todos os estímulos que os atingem e conduzem para a desumanidade ${ }^{22}$. Respondem à vida "com tudo que têm e com mais do que podem" 23 .

Saber valorizar essa santidade primordial depende em boa parte do que se entende por santidade. Perfeição no exercício das virtudes? Imitação de Deus Pai em pessoa, ou da imagem que d'Ele se compõe para uso próprio? Ou resposta radical ao Deus da vida mesmo em meio ao assalto contínuo da morte? Ou esperança contra toda esperança em um Deus que se fez pobre ele mesmo e se alinha ao lado das vítimas e é a única esperança dos crucificados da história?

Essa santidade se constrói em meio a uma criação que continuamente sofre a ameaça de ser destruída. E em sua obstinação em responder positivamente ao Deus Criador desta criação, em meio a todas as atrocidades sem compactuar com ela, consegue viver e lutar pela vida, sua e dos outros. A santidade primordial é aquela que faz resplandecer a beleza da vida em meio a um cotidiano brutal e destrutivo.

É algo que não corresponde à santidade que normalmente se vê nos processos eclesiásticos de canonização. Esses exaltam as virtudes heroicas. Aquela é uma santidade que se expressa em uma vida que é cotidianamente heroica ${ }^{24}$. Pois até para poder ser vida tem que realizar atos constantes de heroísmo. Nesse sentido as vidas dos que vivem essa santidade primordial são milagrosas, pois milagrosamente sobrevivem em um mundo hostil e adverso. E assim dão testemunho de um Deus que é Espírito e Vida e por isso capaz de sustentar o desejo e a força de viver mesmo em meio às maiores agruras e dificuldades.

Como diz belamente Jon Sobrino:

Cf. SOBRINO, Jon. La santidad primordial.

Cf. SOBRINO, Jon. La santidad primordial. No entanto, creio que poucas vezes a teologia se perguntou que excelência tem a vida dessas maiorias.

Cf. TRIGO, Pedro. El Dios de los pobres, p. 245-258, citado em: SOBRINO, Jon. La santidad primordial.

TRIGO, Pedro. El Dios de los pobres.

Cf. SOBRINO, Jon. La santidad primordial, p. 365-377. 
A santidade primordial tem uma lógica diferente à da santidade convencional. E diferentes são suas consequências. Pobres e vítimas não exigem imitação, à qual podem convidar os santos segundo a doutrina oficial. E os santos primordiais raras vezes conseguem que alguém os imite. Mais bem a imitação é recusada por quase todos. Mas onde há bondade de coração, aí sim geram um sentimento de veneração e de querer viver em comunhão com eles ${ }^{25}$.

Parece-nos que em sua exortação que ora examinamos, o olhar de Francisco percebe essa santidade primordial, ao citar o exemplo de pessoas simples e de práticas ainda mais simples, mas não por isso menos santas ( $G E 16)$.

Porém, percorrendo a exortação papal, vemos que esse olhar de Francisco vai mais longe ainda do que os horizontes visíveis e tangíveis que se podem enxergar a olho nu. Ao mesmo tempo em que valoriza enormemente aquela santidade que se dá no cotidiano modesto e aparentemente sem brilho de tantos e tantas, também afirma que isso que é por ele chamado "o rosto mais belo da Igreja" (GE 9) muitas vezes está fora do alcance de sentidos, razão e certamente muito além das fronteiras e dos parâmetros da instituição eclesiástica.

A santidade - tal como a teologia cristã a entende e o Papa explicita na $G E$ - pode acontecer sem direta e necessária conexão com a moralidade, em especial dentro dos parâmetros casuísticos de acordo aos quais a mesma tem sido concebida. Juntamente com esta afirmação, está a convicção de que a santidade não ocorre necessariamente dentro de uma instituição religiosa. Ela é uma transformação completa da pessoa, a qual pode dar-se em diferentes circunstâncias.

O santo é alguém que tem o gênio de contemplar com atenção criativa a realidade e o mundo e encontrar em sua experiência de Deus uma resposta original às demandas e interpelações que seu momento histórico e social levanta. A santidade é, pois, um processo vital que inclui não apenas uma experiência religiosa, mas conecta indissoluvelmente a esta com a ética e a práxis.

\section{SANTIFICAÇÃO = CRISTIFICAÇÃO COM ALGUMAS PREFERÊNCIAS}

Em sua Exortação, Francisco dedica uma longa sessão às Bem-aventuranças, encontrando aí o perfil da santidade tal como o cristianismo a concebe.

$\mathrm{Na}$ verdade, o que as bem-aventuranças mostram - e a $G E$ sublinha - é que ser santo é inspirar-se, seguir e em consequência assemelhar-se sempre mais a Jesus Cristo. Nas bemaventuranças na verdade Jesus traça um retrato de si mesmo. Pois quem mais do que ele é pobre, manso, misericordioso, pacífico e pacificador? Quem mais do que Ele foi faminto e sedento de justiça e perseguido por causa dessa fome e dessa sede? Viver as bem-aventuranças, portanto é assemelhar-se a ele e comportar-se no mundo como ele se comportou.

Por isso Francisco propõe a seguir, no n. 95, o que ele chama de "A grande regra de comportamento". Trata-se da bem-aventurança da misericórdia, aqui retomada de outra perícope evangélica - o capítulo 25 de Mateus - para com o outro necessitado ou infeliz sob qualquer forma e que constitui o caminho reto e correto para o seguimento de Cristo e a união com Ele. Na verdade, trata-se do único caminho de salvação, já que a narrativa se enquadra na figura do juízo escatológico, que decide do destino final de todos os seres humanos criados por Deus. Ali o Juiz Escatológico não postula uma só pergunta sobre a prática religiosa, ou sobre a fidelidade ritualística, ou mesmo sobre o zelo pela correta

25 SOBRINO, Jon. La santidad primordial. 
formulação do conteúdo das crenças. Trata-se de um "exame" sobre a misericórdia, o amor concreto e praticado. E o que aprova ou reprova neste exame é o haver-se ou não atendido, socorrido o outro necessitado com aquilo que ele ou ela necessitam.

Mt 25, 31-46 - texto que marcou indelevelmente a história do cristianismo - traz então uma lista que posteriormente será incorporada pela Igreja em sua Teologia Moral e Catequese como as "obras de misericórdia" 26 . Tais obras dividem-se em dois tipos:

1. as corporais: alimentar os famintos; dar de beber aos quem têm sede; vestir o nu; abrigar os sem abrigo; visitar os doentes; visitar os cativos; sepultar os mortos;

2. as espirituais: instruir os ignorantes; aconselhar os duvidosos; advertir os pecadores; suportar os erros pacientemente; perdoar as ofensas de bom grado; confortar os aflitos; rezar pelos vivos e pelos mortos.

É digno de nota, porém que o evangelista Mateus aponta apenas aquelas entendidas como corporais. Somente elas são mencionadas, no seio das mesmas é que se dá o encontro com Jesus Cristo, sendo ele mesmo o pobre, o faminto, o sedento, o nu que necessita uma veste, o sem abrigo que clama por um teto sobre sua cabeça, por não ter onde repousá-la (cf. Mt 8,20), o cativo privado da liberdade. E o juiz escatológico diz que todo aquele que usa de misericórdia para com uma dessas categorias de pessoas, chamadas respeitosa e afetivamente "meus irmãos mais pequeninos', con-forma seu comportamento misericordioso com o próprio Cristo. Aí, e apenas aí, se encontra o caminho da salvação.

Francisco segue o mesmo caminho. E ao mencionar a via adequada para a santidade, identifica-a com este, que o próprio Ressuscitado traça: Se andamos à procura da santidade que agrada a Deus, neste texto encontramos precisamente uma regra de comportamento com base na qual seremos julgados: "Tive fome e destes-Me de comer, tive sede e destesMe de beber, era peregrino e recolhestes-Me, estava nu e destes-Me que vestir, adoeci e visitastes-Me, estive na prisão e fostes ter comigo [Mt 25, 35-36]" (GE 95).

Não quer isso dizer que o Papa não dê importância às obras de misericórdia espirituais. Pelo contrário. Uma e outra vez ao longo do documento, o Pontífice exorta à paciência, ao cuidado espiritual com o próximo e tudo que constitui a atenção misericordiosa subjetiva e caridosa. Porém, quer deixar bem claro que sem a atenção às necessidades básicas e, portanto, corporais aos pobres e desvalidos da terra, não haverá santidade possível.

E aqui Francisco é muito claro, pois chega ao coração de seu ensinamento sobre o que é a santidade entendida à luz do Evangelho de Jesus Cristo. Trata de exorcizar como tentação uma concepção de santidade que se detém nos êxtases e nos fenômenos extraordinários de uma mística mal compreendida: "ser santo não significa revirar os olhos num suposto êxtase" (GE 96). Afirma outrossim citando a Nuovo Millenio Ineunte, que o texto de Mateus 25, 35-36

"não é um mero convite à caridade, mas uma página de cristologia que projeta um feixe de luz sobre o mistério de Cristo"27. Neste apelo a reconhecê-Lo nos pobres e atribulados, revela-se o próprio coração de Cristo, os seus sentimentos e as suas opções mais profundas, com os quais se procura configurar todo santo ( $G E$ 96).

É com tom solene que o Papa continua exortando explicitamente os fiéis a que recebam essa doutrina, em sua mais profunda e verdadeira autenticidade, sem interpretações que a tergiversem. E aqui vale a citação completa, por sua importância e relevância para o tema da Exortação: 
Perante a força destas solicitações de Jesus, é meu dever pedir aos cristãos que as aceitem e recebam com sincera abertura, "sine glossa", isto é, sem comentários, especulações e desculpas que lhes tirem força. O Senhor deixou-nos bem claro que a santidade não se pode compreender nem viver prescindindo destas suas exigências, porque a misericórdia é o "coração pulsante do Evangelho" $(G E 97)^{28}$.

E prossegue com exemplos concretos, para não deixar dúvidas quanto à doutrina que propõe:

\begin{abstract}
Quando encontro uma pessoa a dormir ao relento, numa noite fria, posso sentir que este vulto seja um imprevisto que me detém, um delinquente ocioso, um obstáculo no meu caminho, um aguilhão molesto para a minha consciência, um problema que os políticos devem resolver e talvez até um monte de lixo que suja o espaço público. Ou então posso reagir a partir da fé e da caridade e reconhecer nele um ser humano com a mesma dignidade que eu, uma criatura infinitamente amada pelo Pai, uma imagem de Deus, um irmão redimido por Jesus Cristo. Isto é ser cristão! Ou poder-se-á porventura entender a santidade prescindindo deste reconhecimento vivo da dignidade de todo o ser humano? $(G E 98)^{29}$
\end{abstract}

A partir dessas afirmações centrais na $G E$, Francisco define então a santidade como estado de permanente insatisfação. Ele denomina mesmo este estado de espírito com uma expressão original: "saudável e permanente insatisfação" ( $G E$ 99). O santo não é nem pode ser uma pessoa acomodada em sua consolação espiritual, vivendo em um espaço sagrado, protegido por uma congregação ou uma diocese ou uma família e uma profissão que lhe garantam um viver tranquilo e confortável, não afetado pelos problemas que afligem boa parte da humanidade. Isso, a médio e longo prazo, leva à doença, à alienação, à anestesia da consciência. Para manter a saúde espiritual, base para toda santidade, há que manter a "insatisfação" que diz respeito não só aos indivíduos como aos sistemas perversos que oprimem e destroem vidas humanas.

Se, como afirma o Papa, "dar alívio a uma única pessoa já justificasse todos os nossos esforços" ( $G E$ 99), Francisco afirma sem deixar lugar a dúvidas: "para nós isso não é suficiente" ( $G E$ 99). Defende então que, não se trata apenas de fazer algumas ações boas, mas de procurar uma mudança social (cf. GE 99). A razão para isso é clara e ele a sustenta citando o documento dos bispos do Canadá por ocasião do Jubileu ${ }^{30}$ : "para que fossem libertadas também as gerações futuras, o objetivo proposto era claramente o restabelecimento de sistemas sociais e económicos justos, a fim de que não pudesse haver mais exclusão".

Francisco segue aí a consciência e o ensinamento de santos de ontem e de hoje. Já os padres da Igreja como Ambrósio de Milão e João Crisóstomo nos séculos IV e V, exortavam a pagar o salário justo ao trabalhador e denunciavam as grandes fortunas que se acumulavam enquanto a maioria vivia na pobreza e na necessidade ${ }^{31}$. Da mesma forma, os Padres Capadócios, responsáveis pelas bases da pneumatologia em nossa teologia, denunciam o sombrio lado estrutural do acúmulo de riquezas e da pobreza que atinge a maioria das pessoas ${ }^{32}$.

O santo deseja não apenas crescer em perfeição particular e pessoal. Deseja transformar o mundo segundo o desejo e o coração de Deus. E transformar o mundo implica não apenas atender as necessidades de cada um, materiais e espirituais, mas igualmente transformar

Citando sua própria bula Misericordiae Vultus (11 de abril de 2015), 12.

Cita a seguir a parábola do Bom Samaritano: "Lembremos a reação do bom samaritano à vista do homem que os salteadores deixaram meio morto na beira da estrada (cf. Lc 10, 30-37).

30 CONFERÊNCIA CANADENSE DOS BISPOS CATÓLICOS - COMISSÃO DE ASSUNTOS SOCIAIS. The Common Good or Exclusion: a Choice for Canadians (1 de fevereiro de 2001), 9, citado em: GE 99, nota 83.

31 AMBRÓSIO DE MILÃO, Sobre Tobias 24, P.L. 14, p. 862; JOÃO CRISÓSTOMO, Sermão 12: Carta a Timóteo, P.G. 62, p. $562-564$.

32 BASÍlIO DE CESAREIA, P.G. 31, p. 262-278; GREGÓRIO DE NISSA, P.G. 46, p 454-469. 
as causas e as circunstancias que geram essas necessidades e esses sofrimentos. Em cada época da história, santos foram os que souberam ler a realidade, ruminá-la e dar suas pessoas inteiramente para transformá-la.

Hoje, com o processo de secularização e de pluralismo com o qual o Cristianismo deve se confrontar, as grandes lutas da humanidade atraem e sensibilizam pessoas de diversas pertenças religiosas. E igualmente pessoas não pertencentes a nenhuma religião. Por isso, muitas vezes podemos ver os santos contemporâneos lutando juntamente com membros de outras religiões e inclusive com ateus por causas que são de toda a humanidade, tais como a justiça, a paz e a liberdade sob diversas formas.

O Papa alerta que nessa santidade que visa o crescimento pessoal, mas também e inseparavelmente o saneamento do espaço público há riscos ideológicos reais. O primeiro é dissociar a transformação social e política da relação com o Senhor e da espiritualidade. E como sempre, exemplifica para maior claridade.

Assim transforma-se o cristianismo numa espécie de ONG, privando-o daquela espiritualidade irradiante que, tão bem, viveram e manifestaram São Francisco de Assis, São Vicente de Paulo, Santa Teresa de Calcutá e muitos outros. A estes grandes santos, nem a oração, nem o amor de Deus, nem a leitura do Evangelho diminuíram a paixão e a eficácia da sua dedicação ao próximo; antes pelo contrário... (GE 100).

Mas não menos real e perigoso é o risco oposto: o de suspeitar e demonizar o compromisso social, acusando-o de ser ateu, de desviar da fé, de estar alinhado a um secularismo sem religião, de ser comunista etc. Já Dom Helder Câmara viveu isso em sua vida e por isso pronunciou essas palavras que até hoje nos inspiram: "Quando dou comida aos pobres, me chamam de santo. Quando pergunto porque eles são pobres, chamam-me de comunista".

Aí Francisco nos brinda com reflexões de muita audácia teológica e sensibilidade pastoral. Propõe como exemplo uma questão altamente delicada e central na moral cristã de hoje: o aborto. Com força, unção e também e não menos, bom senso, afirma:

A defesa do inocente nascituro, por exemplo, deve ser clara, firme e apaixonada, porque neste caso está em jogo a dignidade da vida humana, sempre sagrada, e exige-o o amor por toda a pessoa, independentemente do seu desenvolvimento. Mas igualmente sagrada é a vida dos pobres que já nasceram e se debatem na miséria, no abandono, na exclusão, no tráfico de pessoas, na eutanásia encoberta de doentes e idosos privados de cuidados, nas novas formas de escravatura, e em todas as formas de descarte. Não podemos propor-nos um ideal de santidade que ignore a injustiça deste mundo, onde alguns festejam, gastam folgadamente e reduzem a sua vida às novidades do consumo, ao mesmo tempo que outros se limitam a olhar de fora enquanto a sua vida passa e termina miseravelmente $(G E 101)^{33}$.

E acrescenta com sua dose de realismo e humor habitual que "não se trata da invenção de um Papa nem dum delírio passageiro" (GE 103). Trata-se do coração da Revelação, do fio condutor da auto comunicação de Deus à humanidade, e que diz que fé e justiça caminham de mãos dadas e são inseparáveis. E que a única coisa que agrada a Deus é "repartir o teu pão com os esfomeados, dar abrigo aos infelizes sem casa, atender e vestir os nus e não desprezar o teu irmão. Então, a tua luz surgirá como a aurora" (Is 58, 7-8) (cf. GE 103).

33 E cita aí, no n. 84, o Documento de Aparecida. A V Conferência Geral do Episcopado Latino-Americano, atendo-se ao magistério constante da Igreja, ensinou que o ser humano "é sempre sagrado, desde a sua concepção, em todas as etapas da existência, até à sua morte natural e depois da morte", e que a sua vida deve ser cuidada "desde a concepção, em todas as suas etapas, até à morte natural" (V CONFERENCIA GENERAL DEL EPISCOPADO LATINO-AMERICANO E DO CARIBE, Aparecida. Documento de Conclusão, n. 388, 464). 
Nisto consiste a santidade. Não se trata apenas de multiplicar orações e obedecer rigorosamente a normas morais. Relembra o Papa com gravidade: "o critério de avaliação da nossa vida é, antes de mais nada, o que fizemos pelos outros" ( $G E$ 104). E a oração, por mais preciosa que seja, será autentica e agradará ao Senhor se for a caixa de ressonância dessa prática caritativa e misericordiosa, prática de justiça enfim. Este é o critério que permite não apenas ver o agir do Pai, mas também e não menos, quem são seus verdadeiros filhos. Aqueles que assim vivem são os que chamamos santos, pois são impregnados de Deus, servindo os outros em suas necessidades.

A santidade, então, é a vivencia radical da misericórdia, "é a plenitude da justiça e a manifestação mais luminosa da verdade de Deus" (GE 105) $)^{34}$. Mesmo Tomás de Aquino reafirma essa verdade: a de que

ao interrogar-se quais são as nossas ações maiores, quais são as obras exteriores que manifestam melhor o nosso amor a Deus, responde sem hesitar que, mais do que os atos de culto, são as obras de misericórdia para com o próximo: "não praticamos o culto a Deus com sacrifícios e com ofertas exteriores para proveito d'Ele, mas para benefício nosso e do próximo: de fato Ele não precisa dos nossos sacrifícios, mas quer que Lhos ofereçamos para nossa devoção e para utilidade do próximo. Por isso a misericórdia, pela qual socorremos as carências alheias, ao favorecer mais diretamente a utilidade do próximo, é o sacrifício que mais Lhe agrada" $(G E 106)^{35}$.

Não consiste a santidade apenas em longas horas de oração, jejuns e penitencias que hoje, com a crítica da psicologia, reconhece-se que podem beirar o sadomasoquismo, nem preocupação doentia com uma perfeição que avança à força de pequenos atos, conluios e estratégias que às vezes escondem muito de busca pessoal e subjetiva. Mas ao contrário: "Quem deseja verdadeiramente dar glória a Deus com a sua vida, quem realmente se quer santificar para que a sua existência glorifique o Santo, é chamado a obstinar-se, gastar-se e cansar-se procurando viver as obras de misericórdia" (GE 107).

Assim dizendo, Francisco se aproxima simplesmente daquilo que não cessa de repetir a Bíblia, tanto hebraica como cristã. A $1^{\mathrm{a}}$ carta de João, texto escrito quando as comunidades cristãs já caminhavam há algum tempo e tinham que debater-se com as primeiras heresias, afirma com uma clareza prístina e que não deixa lugar a dúvidas nem a discussões: "Se alguém diz: Eu amo a Deus, e odeia a seu irmão, é mentiroso. Pois quem não ama a seu irmão, ao qual viu, como pode amar a Deus, a quem não viu? E dele temos este mandamento: que quem ama a Deus, ame também a seu irmão" (1 João 4:20,21).

O Papa termina este capítulo de sua exortação, o terceiro e penúltimo, com uma exortação direta aos cristãos católicos para quem sua palavra tem peso como chefe da Igreja:

A força do testemunho dos santos consiste em viver as bem-aventuranças e a regra de comportamento do juízo final. São poucas palavras, simples, mas práticas e válidas para todos, porque o cristianismo está feito principalmente para ser praticado e, se é também objeto de reflexão, isso só tem valor quando nos ajuda a viver o Evangelho na vida diária. Recomendo vivamente que se leia, com frequência, estes grandes textos bíblicos, que sejam recordados, que se reze com eles, que se procure encarná-los. Far-nos-ão bem, tornar-nos-ão genuinamente felizes ( $G E$ 109).

A santidade é então compatível com a felicidade? Parece ser que sim. Porém, o caminho para realmente vive-la deve passar por um constante discernimento.

34 Papa Francisco cita também nas notas desse parágrafo a Bula Misericordiae Vultus, 9 e 10; igualmente, a sua Exortação Amoris laetitia (19 de março de 2016), 311.

Aqui, o papa cita a Suma Teológica do Aquinate (II-II, q. 30, a. 4). 


\section{CONCLUSÃO: O INFINDÁVEL CAMINHO DO DISCERNIMENTO}

Talvez essa seja a síntese conclusiva sobre o que seja a santidade cristã genuína. E o Papa ressalta essa orientação em sua Exortação. Trata-se de um caminho de cada dia do qual fazem parte constitutiva a luta e a vigilância. Nada é dado para sempre na vida segundo o Espírito. Ao contrário, tudo tem que ser buscado diligente e humildemente dia após dia.

Pois o mal existe e, como diz Francisco com todas as letras, o demônio não é um mito. Insidiosamente procura seduzir-nos, infiltrar-se em nossa existência e desviar-nos do caminho do Senhor. Por isso e para que possamos ter consciência de sua presença e lidar lucidamente com os perigos que traz, devemos redobrar a vigilância e sempre estar em atitude alerta e combativa. Menciona a $G E$ os diversos instrumentos que a Igreja põe à disposição dos fiéis para combater as tentações desse que a Escritura chama de Maligno ou Pai da Mentira e reafirma a confiança em que com uma ascese sadia e uma vigilância permanente podemos vencer as tentações que querem impedir-nos de caminhar rumo à santidade e que nos fará semelhantes a Jesus, o Filho de Deus.

O discernimento é o mais importante de todos os caminhos que o Papa recomenda, com zelo paternal, àqueles e àquelas que buscam de todo coração a Deus em seu Filho Jesus Cristo movidos pelo seu Espírito Santo. Em tempos como os nossos, tão nebulosos e arriscados, discernir é algo fundamental. É o que afirma o Pontífice nestes números finais de sua Exortação.

Como é possível saber se algo vem do Espírito Santo ou se deriva do espírito do mundo e do espírito maligno? A única forma é o discernimento. Este não requer apenas uma boa capacidade de raciocinar e sentido comum, é também um dom que é preciso pedir. Se o pedirmos com confiança ao Espírito Santo e, ao mesmo tempo, nos esforçarmos por cultivá-lo com a oração, a reflexão, a leitura e o bom conselho, poderemos certamente crescer nesta capacidade espiritual (GE 166).

Para isso, há que voltar os olhos com confiança aos movimentos interiores que o Espírito faz em nós e aos sinais dos tempos, ou fatos exteriores.

Somos livres, com a liberdade de Jesus, mas Ele chama-nos a examinar o que há dentro de nós - desejos, angústias, temores, expetativas - e o que acontece fora de nós - os "sinais dos tempos" -, para reconhecer os caminhos da liberdade plena: "examinai tudo, guardai o que é bom" (1 Ts 5,21) (GE 168).

Discernir não é escolher entre o bem e o mal. Trata-se de discernir entre o bom e o melhor, percebendo o que é melhor, mais santo, mais excelente, que mais leva ao serviço de Deus e sua glória, que mais coopera para o bem do próximo, sua libertação e salvação. E então sim, guiados e fortificados pelo Espírito Santo, escolher esse caminho: o caminho da santidade. Por isso o discernimento é um caminho que será infindável como infindável é a busca e a experiência do Deus absoluto e infinito por parte da criatura mortal e finita. Seu horizonte é o próprio Jesus Cristo a quem somos chamados a seguir, movidos por Seu Espírito, para maior glória do Pai de todo amor. Trata-se de um horizonte infinito, ao qual seres finitos como nós ousam aspirar. O Papa Francisco nos anima nesse caminho, dizendo que é para nós e que não tenhamos medo de andar por ele. Assim fazendo, estaremos participando da santidade de Deus posta a nosso alcance por Seu Filho e seu Espírito.

\section{REFERÊNCIAS}


AMBRÓSIO DE MILÃO. In: MIGNE J.-P. (ed.), Patrologiae cursus completus, Series latina, XIV, Parisiis, 1844-1864.

BASÍLIO DE CESAREIA. In: MIGNE J.-P. (ed.), Patrologiae cursus completus, Series graeca, XXXI, Parisiis, 1857-1866.

BINGEMER, Maria Clara. Santidade. Chamado à humanidade. Reflexões sobre a Exortação Apostólica Gaudete et Exsultate. São Paulo: Paulinas, 2019.

CLÉMENT, C.; KHAKAR, S. A louca e o santo. Rio de Janeiro: Relume-Dumará, 1997.

BYNUM, Carolyn Walker. Holy Feast and Holy Fast. Berkeley; Los Angeles; London: University of California Press, 1987. https://doi.org/10.1016/0048-721x(90)90105-f

BINGEMER, Maria Clara. Santidade. Chamado à humanidade. Reflexões sobre a Exortação Apostólica Gaudete et Exsultate. São Paulo: Paulinas, 2019.

ENCYCLOPAEDIA UNIVERSALIS. Sainteté. In: Encyclopaedia Universalis. Boulogne-Billancourt [France]. Disponível em: https://www.universalis.fr/encyclopedie/saintete/. Acesso em: 04 dez. 2018. https://doi. org/10.2307/2272105

GREGÓRIO DE NISSA. In: MIGNE J.-P. (ed.), Patrologiae cursus completus, Series graeca, XLVI, Parisiis, 1857-1866.

HOUAISS, Antônio; VILLAR, Mauro de Salles. Sanção. Santo. Dicionário Houaiss da língua portuguesa. Rio de Janeiro: Objetiva, 2001. https://doi.org/10.17979/rlex.2003.9.0.5582

JOÃO CRISÓSTOMO, Sermão 12: Carta a Timóteo. In: MIGNE J.-P. (ed.), Patrologiae cursus completus, Series graeca, LXII, Parisiis, 1857-1866.

KEENAN, James. The Works of Mercy: The Heart of Catholicism. Lanham: Rowman \& Littlefield Publishers, 2007.

MALEGUE, Joseph. Pierres noires. Les classes moyennes du salut. Paris, 1958. https://doi.org/10.2307/40114831

MATHON, G. Sainteté. Catholicisme hier, aujourd'hui et demain, Paris, v. 12, fasc. 61, p. 704. 1992.

OTTO, Rudolf. O Sagrado. São Leopoldo: Editora Sinodal, 2007.

PAPA FRANCISCO. Bula de proclamação do Jubileu extraordinário da misericórdia Misericordiae Vultus (11 de abril de 2015). Disponível em: http://www.vatican.va/content/francesco/pt/apost_letters/documents/ papa-francesco_bolla_20150411_misericordiae-vultus.html. Acesso em: 02 dez. 2018. https://doi.org/10.17771/ pucrio.ateo. 27764

PAPA FRANCISCO. Exortação Apostólica Pós-Sinodal Amoris laetitia (19 de março de 2016). Disponível em: https://w2.vatican.va/content/francesco/pt/apost exhortations/ documents/papa-francesco esortazione-ap_20160319 amoris-laetitia.html. Acesso em: 05 dez. 2018. https://doi.org/10.29386/reb.v77i307.45

PAPA FRANCISCO. Gaudete et exsultate: sobre o chamado à santidade no mundo atual. São Paulo: Paulus, 2018.

PAPA JOÃO PAULO II. Novo Millennio Ineunte (6 de janeiro de 2001). Disponível em: http://www.vatican. va/content/john-paul-ii/pt/apost letters/2001/documents/hf jp-ii apl 20010106 novo-millennio-ineunte. html. Acesso em: 02 dez. 2018.

SANTO INÁCIO DE LOYOLA. Autobiografia. Trad. António Jose Coelho. Braga: Editorial A. O., 2005.

SOBRINO, Jon. La santidad primordial. Concilium, Estella [Navarra], n. 351, p. 365-377. 2013.

SOBRINO, Jon. Terremoto, terrorismo, barbarie y utopía. El Salvador, Nueva York, Afganistán, San Salvador. Madrid: Trotta, 2002; San Salvador: UCA Editores, 2003.

STEIN, Edith. Vida escondida e epifania. Obras Completas. Burgos: Monte Carmelo, 2007. v. 5.

TOMÁS DE AQUINO, Suma teológica. 2. ed. São Paulo: Loyola, 2016. Volume II, parte II.

TRIGO, Pedro. El Dios de los pobres. Revista Latinoamericana de Teología, El Salvador, n. 87, p. 245-258. 2012. 
VASSE, Denis. L'autre du désir ou le Dieu de la foi, Paris, Seuil, 2010.

WEIL, Simone. Attente de Dieu. Lettres écrites du 19 janvier au 26 mai 1942. Disponível em: http://classiques. uqac.ca/classiques/weil_simone/attente_de_dieu/attente_de dieu_1966.pdf. https://doi.org/10.1522/24984951

V CONFERENCIA GENERAL DEL EPISCOPADO LATINO-AMERICANO E DO CARIBE, Aparecida. Documento de Conclusão (29 de junho de 2007), São Paulo 2007.

Recebido em: 27/11/2019

Aceito em: 02/12/2019

Publicado: 29/12/2019

Endereço:

Cátedra Carlo Maria Martini.

Pontifícia Universidade Católica do Rio de Janeiro.

Rua Marquês de São Vicente, 225, Gávea - 22451-900 - Rio de Janeiro, RJ - Brasil 